\title{
Eyebrow Elevation as a Prognostic Factor for Success of Frontalis Suspension in Severe Congenital Ptosis
}

\author{
This article was published in the following Dove Press journal: \\ Clinical Ophthalmology
}

\author{
Amr M Awara (D) \\ Osama E Shalaby \\ Ophthalmology Department, Tanta \\ University, Tanta, Egypt
}

Correspondence: Amr M Awara Ophthalmology Department, Tanta University, Tanta, Egypt

Email amrawara@gmail.com
Purpose: The study aims at evaluating eyebrow elevation as a prognostic factor for frontalis sling procedure success in patients suffering from severe congenital ptosis with poor levator function.

Patients and Methods: This is a retrospective study that included 66 eyelids of 57 patients selected from a surgical $\log$ database between January 2016 and June 2019. All of them underwent frontalis suspension surgery for treating severe congenital myogenic ptosis with poor levator function. Based on the absence or presence of brow elevation, patients were divided into two groups: 1 and 2, respectively. The latter was further subdivided into subgroup A with unilateral brow elevation and subgroup B with bilateral brow elevation. All included cases completed 6 months of follow-up after surgery. Postoperative functional outcomes in the form of margin reflex distance (MRD1) and palpebral aperture (PA) were recorded and correlated to preoperative brow elevation status.

Results: Both principal groups showed improvement of MRD1 and PA compared to the preoperative values. There was no statistically significant difference between both groups for the tested parameters in the 1st postoperative week. By the 6th postoperative month, MRD1 and PA showed statistically significant higher values in group 2 compared to group 1 $(p<0.001)$. However, the difference between subgroups A and B was statistically insignificant for the same parameters.

Conclusion: Eyebrow elevation is significantly associated with the success of frontalis suspension procedure. Hence, brow position evaluation should be included in the preoperative assessment of patients undergoing frontalis suspension for congenital ptosis.

Keywords: frontalis suspension, congenital ptosis, brow elevation

\section{Introduction}

Congenital blepharoptosis is a developmental dystrophy of the levator muscle complex that can be unilateral or bilateral. It may affect visual function in addition to its cosmetic effect. ${ }^{1}$

The surgical approach for correcting such problem markedly depends on the severity of ptosis and the degree of levator function. Frontalis suspension surgery is advocated for severe cases with poor levator function. This surgery connects the eyelid to the brow with a sling material in order to utilize the power of the frontalis muscle to elevate the eyelid. It can be performed either unilaterally or bilaterally with good functional and cosmetic results. ${ }^{2-4}$ Various surgical techniques using different autogenous or exogenous materials have been described. Each technique has its own advantages and disadvantages with variable success rates. ${ }^{5}$

The eyebrow has an intimate physiological and anatomical relationship with the eyelids and it plays an important role in facial expressions. Eyebrow elevation is 
a natural compensatory response to blepharoptosis in order to clear the visual axis. The frontalis muscle primarily elevates the forehead and eyebrows. It acts as an accessory upper lid elevator providing additional 3 to $5 \mathrm{~mm}$ of lid elevation at maximal action. ${ }^{6,7}$

The aim of this study is to evaluate preoperative eyebrow elevation as a prognostic factor in the success of frontalis sling procedure for patients suffering from severe congenital ptosis and poor levator function.

\section{Patients and Methods}

\section{Study Design and Participants}

This is a retrospective study that took place in Tanta University Hospital (Tertiary eye hospital in Egypt) between January 2016 and June 2019. This study adhered to the tenets of the Declaration of Helsinki and was conducted after the approval of the ethical review committee of Faculty of Medicine, Tanta University. A written informed consent was signed by the parents/legal guardians of every patient prior to participation including consent of image publication.

Data records and photographs of 57 patients (66 eyelids) with severe congenital myogenic ptosis and poor levator function were revised. Severe ptosis was defined as: marginal reflex distance $(\mathrm{MRD} 1) \leq 1 \mathrm{~mm}$ while poor levator muscle function (LF) was defined as: $\mathrm{LF} \leq 4 \mathrm{~mm}$. Children with synkinetic movements of the upper lid, congenital neurogenic ptosis, acquired blepharoptosis and strabismus were excluded from the study.

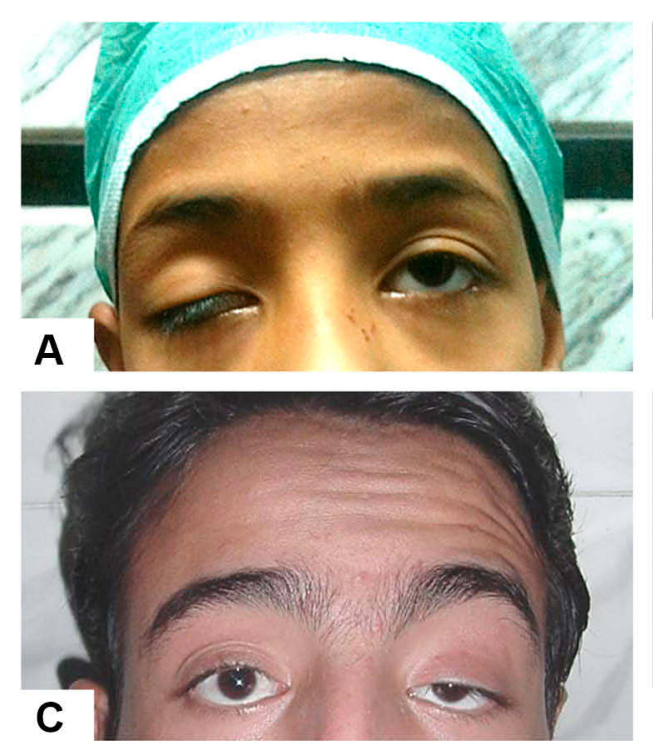

Preoperative chart records were revised for history, visual acuity, extraocular muscle movements, Bell's phenomenon and pupillary reaction whenever these examinations were feasible. Ptosis examination data included LF, MRD1, palpebral aperture (PA) values, brow elevation, lid lag and chin up face position.

According to the presence of brow elevation, patients were classified into two principal groups of 33 eyelids each;

Group 1: included 33 eyelids (33 patients) without brow elevation in the primary position.

Group 2: included 33 eyelids ( 24 patients) with brow elevation in the primary position. Patients were further subdivided into 2 subgroups;

Subgroup 2A included patients who had unilateral ptosis and unilateral brow elevation in the primary position (15 patients, 15 eyelids) while subgroup 2B included patients who had bilateral ptosis with bilateral brow elevation in the primary position ( 9 patients, 18 eyelids).

The degrees of ptosis, brow elevation as well as brow position asymmetry were assessed clinically. Brow asymmetry was defined as: a measured eyebrow height difference in conjunction with the asymmetric recruitment of the frontalis muscle. ${ }^{8}$ Figure 1 illustrates different clinical presentations of patients included in the study.

All patients in the study had undergone frontalis sling surgery by two surgeons using the standard FoxPentagonal technique and utilizing the polytetrafluoroethylene (PTFE) "Gore-Tex" CV-2. At the end of the surgery, eyelid margin position was to be at the superior limbus. ${ }^{9}$
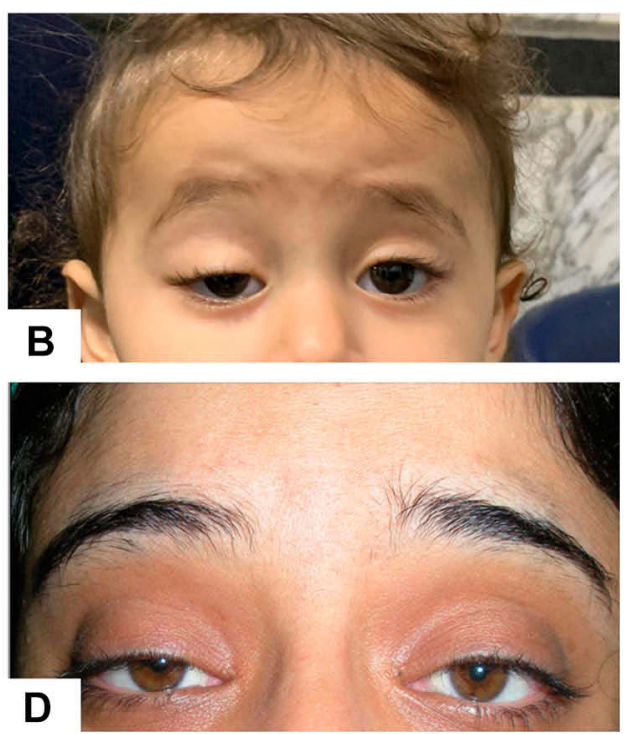

Figure I (A) Severe ptosis without brow elevation (group I). (B) Brow elevation with faint forehead corrugations (group 2A). (C) Unilateral brow elevation with marked transverse forehead rhytides (group 2A). (D) Bilateral brow elevation (group 2B). 
Patients who completed the 6 months of follow up were included in the study. Two independent observers evaluated the recorded postoperative data of MRD1 and PA at 1 st week and 6th month post-operative visits. Data were compared to the preoperative measurements.

\section{Statistical Analysis}

Data were analyzed by SPSS statistical package version 23 (SPSS Inc. Released 2015. IBM SPSS statistics for windows, version 23.0, Armonk, NY: IBM Corp.) and expressed in: Number (No), percentage (\%) mean $(\bar{x})$ and standard deviation (SD). Student's $t$-test is a test of significance used for comparison of quantitative variables between two groups of normally distributed data, while Mann Whitney's test was used for comparison of quantitative variables between two groups of not normally distributed data. Repeated measures ANOVA (with or without Bonferroni correction) with Mauchly test for sphericity test were used for comparison among three or more consecutive measures in the same group of quantitative variables. Assumed sphericity was used for normally distributed data while Greenhouse-Geisser was used for not normally distributed data. Chi-square test $\left(\chi^{2}\right)$ was used to study association between qualitative variables and whenever any of the expected cells were less than five; Fischer's Exact test was used. A logistic regression model was performed to ascertain the effects of preoperative brow elevation on the 6th month MRD1 and PA. Two-sided P-value of $<0.05$ was considered statistically significant.

\section{Results}

The two principle groups were comparable as regards age, gender or eye side distribution (Table 1).

There was no significant difference between the two principal groups as regards the preoperative MRD1 or PA. All patients in group 2 had preoperative elevated eyebrow
Table I Patients' Characteristics of the 2 Groups

\begin{tabular}{|l|l|l|l|}
\hline Characteristics & $\begin{array}{l}\text { Group I (n=33 } \\
\text { Lids) No. (\%) }\end{array}$ & $\begin{array}{l}\text { Group 2 (n=33 } \\
\text { Lids) No. (\%) }\end{array}$ & P value \\
\hline $\begin{array}{l}\text { Age (y) mean } \\
\pm \text { SD } \\
\text { Range }\end{array}$ & $\begin{array}{l}6.20 \pm 3.28 \\
(2-18)\end{array}$ & $\begin{array}{l}7.00 \pm 4.99 \\
(1.5-19)\end{array}$ & 0.990 \\
\hline $\begin{array}{l}\text { Eye } \\
\text { Right } \\
\text { Left }\end{array}$ & $19(57.6)$ & $18(54.5)$ & 0.804 \\
\hline $\begin{array}{l}\text { Gender (by } \\
\text { patient) } \\
\text { Male } \\
\text { Female }\end{array}$ & $14(42.4)$ & $15(45.5)$ & \\
\hline
\end{tabular}

that was either associated with mild forehead corrugations $(83.3 \%)$ of cases or transverse forehead rhytides (16.7\%). By the end of the 1st postoperative week, both measurements showed statistically significant increase ( $p$ $<0.001)$ as compared to the preoperative values in both groups. PA was significantly higher in group 2 compared to group 1 (p 0.034). MRD1 and PA in both groups showed significant reduction in measurements towards the end of the 6th postoperative month compared to the first week, however, they remained significantly higher than the preoperative values in both groups $(p<0.001)$ (Figure 2). MRD1 and PA measurements were higher in group 2 with statistically significant difference compared to group 1 ( $p<0.001$ and 0.029 , respectively) (Table 2 ). More details of all the cases' data are supplied in the Supplementary material.

In the first postoperative visit, $94 \%$ of patients in group 2 had the elevated brow back to normal position while it remained elevated in $6 \%$ of patients. The latter percentage increased to $9.1 \%$ by the 6 th postoperative month. The difference of brow position between subgroups $\mathrm{A}$ and B was statistically insignificant in both postoperative visits (p 0.150 and 0.076 , respectively) (Figures 3 and 4).
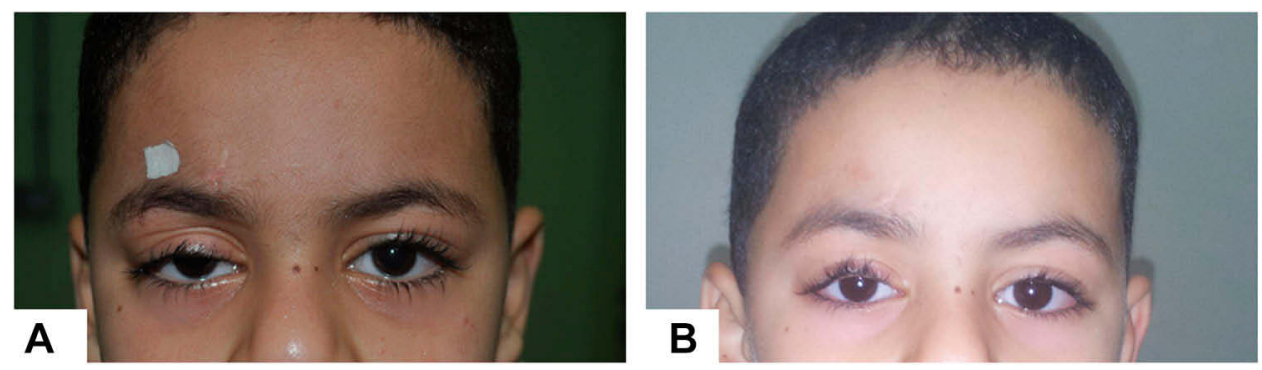

Figure 2 (A) Rt severe ptosis without brow elevation. (B) At the 6th month postoperative. 
Table 2 Comparison of Postoperative Outcome Between Group I and Group 2 Following Frontalis Suspension at I Week and 6 Months After Surgery

\begin{tabular}{|c|c|c|c|}
\hline Characteristics & $\begin{array}{l}\text { Group I } \\
\text { (n=33 Lids) } \\
\text { Mean } \pm \text { SD } \\
\text { Median } \\
\text { Range }\end{array}$ & $\begin{array}{l}\text { Group } 2 \\
(n=33 \text { Lids) } \\
\text { Mean } \pm \text { SD } \\
\text { Median } \\
\text { Range }\end{array}$ & P value \\
\hline $\begin{array}{l}\text { Preoperative } \\
\text { MRDI }\end{array}$ & $\begin{array}{l}0.09 \pm 0.83 \\
0.0 \\
-1.0 \text { to } 1.0\end{array}$ & $\begin{array}{l}0.36 \pm 0.67 \\
0.50 \\
-1.0 \text { to } 1.0\end{array}$ & 0.209 \\
\hline Ist Week MRDI & $\begin{array}{l}3.30 \pm 0.88 \\
3.0 \\
0.0 \text { to } 4.0\end{array}$ & $\begin{array}{l}3.42 \pm 0.69 \\
3.0 \\
2.0 \text { to } 4.0\end{array}$ & 0.716 \\
\hline 6th Month MRDI & $\begin{array}{l}1.62 \pm 1.16 \\
2.0 \\
0.0 \text { to } 4.0\end{array}$ & $\begin{array}{l}2.06 \pm 1.29 \\
2.0 \\
-1 \text { to } 4.0\end{array}$ & $<0.001$ \\
\hline$P$ value & $\begin{array}{l}<0.001 \\
\mathrm{PI}<0.001 \\
\mathrm{P} 2<0.001 \\
\mathrm{P} 3<0.001\end{array}$ & $\begin{array}{l}<0.00 \mathrm{I} \\
\mathrm{PI}<0.00 \mathrm{I} \\
\mathrm{P} 2<0.00 \mathrm{I} \\
\mathrm{P} 3<0.00 \mathrm{I}\end{array}$ & \\
\hline Preoperative PA & $\begin{array}{l}3.87 \pm 0.69 \\
4.0 \\
3.0 \text { to } 5.0\end{array}$ & $\begin{array}{l}4.06 \pm 0.56 \\
4.0 \\
3.0-5.0\end{array}$ & 0.250 \\
\hline Ist Week PA & $\begin{array}{l}6.13 \pm 0.80 \\
6.0 \\
3.5 \text { to } 7.0\end{array}$ & $\begin{array}{l}6.56 \pm 0.68 \\
6.75 \\
5.0 \text { to } 7.5\end{array}$ & 0.024 \\
\hline 6th Month PA & $\begin{array}{l}4.59 \pm 1.20 \\
5.0 \\
3.0 \text { to } 8.0\end{array}$ & $\begin{array}{l}5.22 \pm 1.20 \\
5.0 \\
3.0 \text { to } 7.0\end{array}$ & 0.029 \\
\hline$P$ value & $\begin{array}{l}<0.00 \mathrm{I} \\
\mathrm{PI}<0.00 \mathrm{I} \\
\mathrm{P} 2<0.00 \mathrm{I} \\
\mathrm{P} 3<0.00 \mathrm{I}\end{array}$ & $\begin{array}{l}<0.001 \\
\mathrm{PI}<0.00 \mathrm{I} \\
\mathrm{P} 2<0.00 \mathrm{I} \\
\mathrm{P} 3<0.001\end{array}$ & \\
\hline
\end{tabular}

Abbreviations: PI, preoperative vs Ist week; P2, preoperative vs 6th month, P3, Ist week vs 6th month; MRDI, margin reflex distance I, PA, palpebral aperture.

The subgroups $2 \mathrm{~A}$ and $2 \mathrm{~B}$ were comparable as regards age, sex and preoperative MRD1 or PA measurements. The mean age of subgroup 2A was $7.20 \pm 4.60$ (range: $2-17 \mathrm{y})$ compared to $6.83 \pm 5.42$ y (range: $1.5-22 \mathrm{y}$ ) in subgroup $2 \mathrm{~b}$ ( $\mathrm{P}$ value: 0.835 ). Males represented $53.3 \%$ of group $2 \mathrm{~A}$ and $44.4 \%$ of group $2 \mathrm{~B}$ with (p value 0.732 ).

MRD1 and PA measurements increased significantly in both subgroups by the 1st postoperative week compared to their preoperative values $(p<0.001)$. Both parameters were higher in subgroup 2A compared to subgroup 2B (p 0.012 and 0.018 , respectively). By the end of the 6 th postoperative month; both measurements decreased compared to the 1 st week yet remained significantly higher than the preoperative values $(\mathrm{p}<0.001)$ with no statistically significant difference between the 2 subgroups (Table 3 )

By the end of the 6th postoperative month, the linear regression model of the effect of preoperative brow status showed a non-significant model on the MRD1 (p 0.153) and a significant effect on the PA (p 0.036) with OR 0.259 (95\% CI 0.044-1.22).

\section{Discussion}

Most patients with severe ptosis recruit the ipsilateral frontalis muscle to elevate their eyelid as a compensatory mechanism. Kersten et al, noticed that in unilateral ptosis, frontalis recruitment is unilateral and is limited to the ptotic side while in bilateral ptosis; asymmetric frontalis contraction occurs if one eye is amblyopic. ${ }^{3}$ In the current study, we noticed brow elevation to be asymmetrical in patients with bilateral asymmetric ptosis and symmetrical in bilateral symmetrical ptosis causing a surprised look. Frontalis muscle contraction in young children induces eyebrow elevation with faint forehead corrugations that develop into marked horizontal rhytides in teenagers with longstanding contraction.

McCullough et al discussed the mechanisms of eyebrow elevation in blepharoptosis in sighted and prosthetic eyes. They concluded that frontalis contraction and brow elevation occurred in blepharoptosis not only due to visual incentive to clear visual axis but also due to eyelid proprioception as in patients with ocular prosthesis. ${ }^{10}$

Attaching the frontalis muscle to the tarsal plate via various sling materials allows the frontalis action to elevate the ptotic eyelid more efficiently. Hence, the
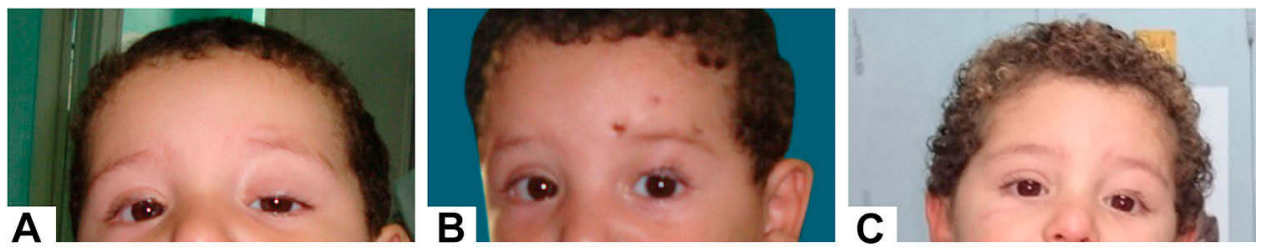

Figure 3 (A) Lt severe ptosis with brow elevation. (B) First postoperative week with return of brow to normal position. (C) At the 6th postoperative month. 

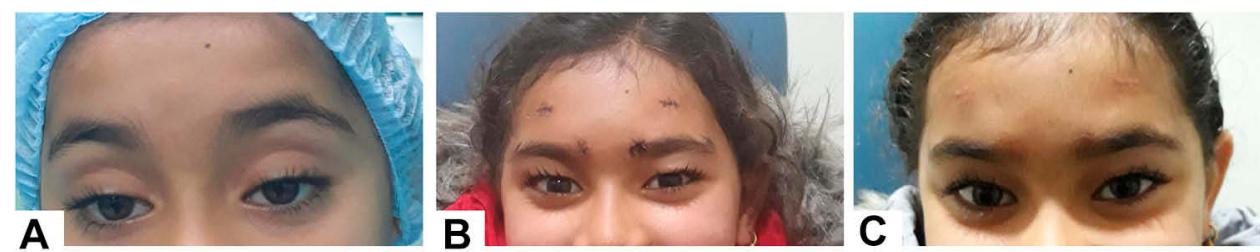

Figure 4 (A) Bilateral severe ptosis with brow elevation giving surprised look. (B) Bilateral frontalis sling with return of brows to normal position at the Ist week postoperative. (C) At the 6th postoperative month.

outcome of frontalis suspension surgery is highly affected by the frontalis muscle contraction. Different surgical techniques and various sling materials were evaluated in

Table 3 Comparison of Postoperative Outcome Between Group 2A and 2B Following at I Week and 6 Months Postoperative

\begin{tabular}{|c|c|c|c|}
\hline Characteristics & $\begin{array}{l}\text { Subgroup 2A } \\
\text { ( } n=15 \text { Lids) } \\
\text { Mean } \pm S D \\
\text { Median } \\
\text { Range }\end{array}$ & $\begin{array}{l}\text { Subgroup 2B } \\
\text { ( } n=18 \text { Lids) } \\
\text { Mean } \pm \text { SD } \\
\text { Median } \\
\text { Range }\end{array}$ & $P$ value \\
\hline Preoperative MRDI & $\begin{array}{l}0.23 \pm 0.77 \\
0.0 \\
-1.0 \text { to } 1.0\end{array}$ & $\begin{array}{l}0.47 \pm 0.58 \\
0.50 \\
-1.0 \text { to } 1.0\end{array}$ & 0.419 \\
\hline Ist Week MRDI & $\begin{array}{l}3.73 \pm 0.67 \\
4.0 \\
2.0 \text { to } 4.50\end{array}$ & $\begin{array}{l}3.16 \pm 0.61 \\
3.0 \\
2.0 \text { to } 4.0\end{array}$ & 0.012 \\
\hline 6th Month MRDI & $\begin{array}{l}2.06 \pm 1.33 \\
2.0 \\
3.0 \text { to } 5.0\end{array}$ & $\begin{array}{l}2.05 \pm 1.30 \\
2.0 \\
-1 \text { to } 4.0\end{array}$ & 0.696 \\
\hline$P$ value & $\begin{array}{l}<0.001 \\
\mathrm{PI}<0.001 \\
\mathrm{P} 2<0.001 \\
\mathrm{P} 3<0.001\end{array}$ & $\begin{array}{l}<0.001 \\
\mathrm{PI}<0.001 \\
\mathrm{P} 2<0.001 \\
\mathrm{P} 3<0.007\end{array}$ & \\
\hline Preop PA & $\begin{array}{l}4.20 \pm 0.70 \\
4.0 \\
3.0 \text { to } 5.0\end{array}$ & $\begin{array}{l}3.94 \pm 0.41 \\
4.0 \\
3.0 \text { to } 4.50\end{array}$ & 0.222 \\
\hline Ist Week PA & $\begin{array}{l}6.83 \pm 0.55 \\
7.0 \\
5.50 \text { to } 7.5\end{array}$ & $\begin{array}{l}6.33 \pm 0.70 \\
6.25 \\
5.0 \text { to } 7.5\end{array}$ & 0.034 \\
\hline 6th Month PA & $\begin{array}{l}5.20 \pm 1.29 \\
5.0 \\
3.50 \text { to } 7.0\end{array}$ & $\begin{array}{l}5.25 \pm 1.16 \\
5.0 \\
3.0 \text { to } 7.0\end{array}$ & 0.868 \\
\hline$P$ value & $\begin{array}{l}<0.001 \\
\mathrm{PI}<0.001 \\
\mathrm{P} 2<0.139 \\
\mathrm{P} 3<0.003\end{array}$ & $\begin{array}{l}<0.00 \mathrm{I} \\
\mathrm{PI}<0.001 \\
\mathrm{P} 2<0.001 \\
\mathrm{P} 3<0.003\end{array}$ & \\
\hline
\end{tabular}

Abbreviations: $\mathrm{PI}$, preoperative vs Ist week, $\mathrm{P} 2$, preoperative vs 6th month; $\mathrm{P}$, Ist week vs 6 th month; MRDI, margin reflex distance I; PA, palpebral aperture. order to reduce the high recurrence rates with variable results. ${ }^{11-13}$

The lid position in the 1st postoperative week showed no significant difference between non-elevated and elevated brow groups. This is probably due to the mechanical power of the placed sling that elevates the eyelid rather than the frontalis contraction. On the other hand, patients with preoperative brow elevation had significantly higher lid position with less recurrence rate by the 6th postoperative month. This is due to the sustained frontalis contraction that gave continuous power to the sling thread for eyelid suspension. Accordingly, brow elevation should be taken into consideration when using synthetic, inert, monofilament material like Gore-Tex that does not cause inflammation or fibrosis along its track; as it depend on frontalis muscle contraction all the time to elevate the eyelid.

The elevated preoperative brow reflected better function of the frontalis muscle which was enhanced after suspension with the synthetic material. This was evident by the better results of MRD1 and PA at the 6th postoperative month among patients in group 2 compared to group 1 . The results remained the same for both symmetric and asymmetric brow elevation with no significant difference between the studied subgroups.

O'Donnell et al concluded that patients presented with good vision on the normal side have little incentive to raise the ptotic lid using the frontalis muscle with subsequent brow relaxation and sling failure. They also stated that those with asymmetric eyebrows; try to raise the ptotic eyelid with brow elevation once the lid is suspended. ${ }^{14}$

During the follow up of our patients, we noticed that $6 \%$ of still had eyebrow asymmetry in the early postoperative period; due to mild ptosis in the contralateral eye. This percentage increased to $9.1 \%$ by the 6th postoperative month as the eyelid started to fall interfering with vision, hence stimulating the compensatory frontalis contraction with subsequent eyebrow asymmetry.

To our knowledge, there are no previous studies with statistical analysis that discussed the direct impact of 
preoperative eyebrow elevation on frontalis suspension surgery outcome.

\section{Recommendations}

From what we observed during this study, we recommend that surgeons adjust the eyelid margin $1 \mathrm{~mm}$ above the limbus in the patients who do not have preoperative brow elevation to compensate for the late undercorrection.

\section{Study Limitations}

Because of the retrospective nature of the study, there was no standardized protocol for the preoperative photographs used to assess frontalis recruitment and that is just a single point in time which may not be representative of the child's normal brow, recruitment, and that the reviewer of the preoperative photographs was not blinded to the surgical outcome. The lack of long-term follow data of the patients.

\section{Conclusion}

The presence of preoperative brow elevation is significantly associated with better and sustained success of frontalis sling operation. The assessment of brow elevation should be included in the preoperative evaluation of patients with congenital ptosis undergoing this procedure.

\section{Disclosure}

The authors report no conflicts of interest in this work.

\section{References}

1. Soohoo JR, Davies BW, Allard FD, Durairaj VD. Congenital ptosis. Surv Ophthalmol. 2014;59(5):483-492. doi:10.1016/j.survophthal.20 14.01.005
2. Ho YF, Wu SY, Tsai YJ. Factors associated with surgical outcomes in congenital ptosis: a 10-year study of 319 cases. Am J Ophthalmol. 2017;175:173-182. doi:10.1016/j.ajo.2016.12.013

3. Kersten RC, Bernardini FP, Khouri L, Moin M, Roumeliotis AA, Kulwin DR. unilateral frontalis sling for the surgical correction of unilateral poor-function ptosis. Ophthalmic Plast Reconstr Surg. 2005;21(6):412-6; discussion 416-7. doi:10.1097/01.iop.00001 80068.17344 .80

4. Helveston EM, Wilson DL. A suture-reinforced scleral sling. Technique for suspension of the ptotic upper lid. Arch Ophthalmol. 1975;93:643-645. doi:10.1001/archopht.1975.01010020609010

5. Takahashi Y, Leibovitch I, Kakizaki H. Frontalis suspension surgery in upper eyelid blepharoptosis. Open Ophthalmol J. 2010;4:91-97. doi: $10.2174 / 1874364101004010091$

6. Knize D. An anatomically based study of the mechanism of eyebrow ptosis. Plast Reconstr Surg. 1996;97:1321. doi:10.1097/00006534199606000-00001

7. Lemke BN, Stasior OG. The anatomy of eyebrow ptosis. Arch Ophthalmol. 1982;100:981. doi:10.1001/archopht.1982.010300309 89019

8. Shah CT, Nguyen EV, Hassan AS. Asymmetric eyebrow elevation and its association with ocular dominance. Ophthalmic Plast Reconstr Surg. 2012;28(1):50-53. doi:10.1097/IOP.0b013e3182364 aea

9. Fox SA. Congenital ptosis frontalis single pentagon (Fox procedure). J Pediatr Ophthalmol. 1966;3:25-28.

10. McCullough A, Rosenberg C, Lelli G Jr., Lisman R. Mechanisms of eyebrow elevation in acute ptosis in sighted and prosthetic eyes. Invest Ophthalmol Vis Sci. 2010;51:1474.

11. Ben Simon GJ, Macedo AA, Schwarcz RM, Wang DY, McCann JD, Goldberg RA. Frontalis suspension for upper eyelid ptosis: evaluation of different surgical designs and suture material. $\mathrm{Am}$ J Ophthalmol. 2005;140:877-885.

12. Wagner RS, Mauriello JA Jr, Nelson LB, et al. Treatment of congenital ptosis with frontalis suspension: a comparison of suspensory materials. Ophthalmology. 1984;91:245-248. doi:10.1016/S01616420(84)34298-1

13. Steinkogler FJ, Kuchar A, Huber E, Arocker-Mettinger E. Gore-Tex soft-tissue patch frontalis suspension technique in congenital ptosis and in blepharophimosis-ptosis syndrome. Plast Reconstr Surg. 1993;92(6):1057-1060. doi:10.1097/00006534-199311000-00009

14. O'donnell B, Codère F, Dortzbach R, Lucarelli M, Kersten R, Rosser P. Clinical controversy: congenital unilateral and Jaw-Winking ptosis. Orbit. 2006;25:11-17. doi:10.1080/0167683 0500544185
Clinical Ophthalmology

\section{Publish your work in this journal}

Clinical Ophthalmology is an international, peer-reviewed journal covering all subspecialties within ophthalmology. Key topics include: Optometry; Visual science; Pharmacology and drug therapy in eye diseases; Basic Sciences; Primary and Secondary eye care; Patient Safety and Quality of Care Improvements. This journal is indexed on PubMed

\section{Dovepress}

Central and CAS, and is the official journal of The Society of Clinical Ophthalmology (SCO). The manuscript management system is completely online and includes a very quick and fair peer-review system, which is all easy to use. Visit http://www.dovepress.com/ testimonials.php to read real quotes from published authors. 